\title{
The Serotonin Receptor 2A Gene Moderates the Influence of Parental Socioeconomic Status on Adulthood Harm Avoidance
}

\author{
Markus Jokela · Terho Lehtimäki • \\ Liisa Keltikangas-Järvinen
}

Received: 28 August 2006/Accepted: 11 April 2007/Published online: 9 May 2007

(C) Springer Science+Business Media, LLC 2007

\begin{abstract}
We examined whether the T102C polymorphism of the serotonin receptor 2A gene (HTR2A) moderated the influence of childhood or adolescence parental socioeconomic status (SES) on adulthood temperament trait harm avoidance (HA) in a population-based sample of 1246 healthy Finnish men and women, who were 2439 years of age in the last follow-up phase. High parental $\mathrm{SES}$ predicted low adulthood HA. In addition, the $\mathrm{C}$ allele of the T102C polymorphism was associated with high HA in one of the two test settings, and with the mean of the two measurements. Most importantly, we found that the T102C polymorphism moderated the influence of parental SES, such that high parental SES predicted low adulthood HA in subjects with the T/T or T/C genotypes, while this was not true for those carrying the $\mathrm{C} / \mathrm{C}$ genotype. The role of the T102C polymorphism was most pronounced among those with high parental SES. We conclude that the T102C polymorphism of the HTR2A gene may be involved in the development of temperament by moderating the influence of environmental conditions.
\end{abstract}

Keywords Temperament - Personality development . Gene-environment interaction · HTR2A · TCI · Childhood

Edited by Peter McGuffin

M. Jokela · L. Keltikangas-Järvinen ( $\square)$

Department of Psychology, University of Helsinki, P. O. Box 9,

Helsinki 00014, Finland

e-mail: liisa.keltikangas-jarvinen@helsinki.fi

T. Lehtimäki

Laboratory of Atherosclerosis Genetics, Tampere University

Hospital, Centre for Laboratory Medicine and Department of

Clinical Chemistry, Medical School at the University of

Tampere, Tampere, Finland

\section{Introduction}

In the biosocial model of personality proposed by Cloninger and colleagues (Cloninger et al. 1987, 1993), temperament refers to biases in automatic responses to emotional stimuli. This model distinguishes four temperament traits: novelty seeking, harm avoidance, reward dependence and persistence. The traits are postulated to have independent genetic and neurobiological bases and to modulate responses to reinforcement and different classes of emotional stimuli. Temperament is involved in a wide range of developmental processes such as socialization (Kochanska 1991), cognitive development (Raine et al. 2002) and physical health (Keltikangas-Järvinen et al. 1999). The most important outcome of temperament is adulthood personality (McCrae et al. 2000).

Temperament is of high relevance in the context of stress, since it may determine what individuals perceive as stressful and how they respond to stressful stimuli (Bolger and Schilling 1991). It may therefore play a role in individual stress vulnerability (Fanous et al. 2002).

Even though temperament has a genetic basis, appears early in life and is relatively stable over time (McCrae et al. 2000), its manifestation may depend on environmental factors (Fox et al. 2005). Parental socioeconomic status (SES) is one of the most extensively studied factors of children's developmental environment. Parental SES is a global construct reflecting the availability of social, financial and human capital for the child (Bradley and Corwyn 2002). The effects of parental SES are observed in almost every domain of development, including social, cognitive and somatic development (see Bradley and Corwyn 2002; Repetti et al. 2002). Concerning stress, parental SES has been associated with socio-emotional development and coping skills, so that children with high parental SES tend 
to become more resilient to stress later in life than children with low parental SES (see Bradley and Corwyn 2002; Repetti et al. 2002).

Accumulating evidence from molecular genetic studies suggests that genes may moderate the influence of environmental factors on behavioral endpoints (Berman and Noble 1997; Ozkaragoz and Noble 2000; Caspi et al. 2003; Eley et al. 2004; Fox et al. 2005; Grabe et al. 2005). In the context of human behavior, the first molecular studies on gene-environment interactions were carried out by Noble and colleagues, who found the dopamine receptor gene DRD2 to moderate the impact of family stress on cognitive functioning (Berman and Noble 1997) and personality (Ozkaragoz and Noble 2000) in adolescent boys. The interaction between dopamine receptor gene DRD4 and hostile childhood environment has also been shown to result in high levels of novelty seeking (Keltikangas-Järvinen et al. 2004). Studies investigating the serotonergic system have shown that the serotonin transporter gene 5-HTTLPR polymorphism may moderate the impact of negative life events on depression (Caspi et al. 2003; Eley et al. 2004) and physical health (Grabe et al. 2005). In addition, Manuck et al. (2004) found the 5-HTTLPR to moderate the association between adulthood SES and serotonergic functioning.

The purpose of the present study was to examine whether allelic variation in the T102C polymorphism of the serotonin receptor $2 \mathrm{~A}$ gene (HTR2A) moderates the association between parental SES in childhood and adolescence and temperamental harm avoidance (HA) in adulthood. According to Cloninger (Cloninger et al. 1987) HA refers to behavioral inhibition and reactivity to aversive stimuli, and individuals with high HA are characterized as inhibited, cautious and fearful. HA has been shown to be related to stress vulnerability (Puttonen et al. 2005), and high HA may increase the susceptibility to affective disorders, such as depression (Farmer et al. 2003). Cloninger (Cloninger et al. 1987) suggested that serotonin is the primary neurotransmitter underlying HA. This assumption has been supported by neuroendocrinological (Peirson et al. 1999, Hansenne and Ansseu 1999) and genetic (Munafò et al. 2005) evidence.

The HTR2A gene in particular may be considered as a candidate gene for HA, since the binding potential of the $5-\mathrm{HT}_{2 \mathrm{~A}}$ receptors has been associated with $\mathrm{HA}$ (van Heeringen et al. 2003) and related traits (Moresco et al. 2002). The T102C polymorphism of the HTR2A gene has been associated with the binding potential of the $5-\mathrm{HT}_{2 \mathrm{~A}}$ receptors (Turecki et al. 1999), and with $5-\mathrm{HT}_{2 \mathrm{~A}}$ receptor mRNA levels in postmortem brain (Polesskaya and Sokolov 2002). These findings suggest that there might be an association between the T102C polymorphism and HA. This suggestion has, however, not been supported by studies carried out this far (Kusumi et al. 2002; Schüssler et al. 2000). The functional significance of the T102C polymorphism has also been questioned by a study (Bray et al. 2004) that found no evidence of polymorphisms in the HTR2A gene affects mRNA levels in the adult brain. These conflicting findings emphasize the need for additional studies.

We hypothesized that the $\mathrm{C}$ allele of the T102C polymorphism and low parental SES in childhood and adolescence are associated with high adulthood HA, and that the association between parental SES and adulthood HA is moderated by the T102C polymorphism. In order to provide a more reliable assessment of temperament, temperament was measured in two test settings taken four years apart. The independent role of parental SES was evaluated by controlling for the subject's own adulthood SES.

\section{Materials and methods}

\section{Subjects}

The subjects were 1246 healthy men $(n=559)$ and women $(n=687)$ participating in the on-going population-based study of 'Cardiovascular Risk in Young Finns' (CRYF; Åkerblom et al. 1991). In this prospective epidemiological study, a randomly selected sample of 3596 Finnish healthy children and adolescents from six birth cohorts (aged 3, 6, 9, 12, 15 and 18 years at the baseline) has been followed since 1980, with a focus on the development of risk factors of coronary heart disease. In the present study, a subsample of 1593 participants was selected at random for genotyping and, depending on the availability of temperament assessments, 966-1246 subjects had complete data (see Tables 1 and 2). All the subjects gave their written informed consent and gave blood samples in accordance with the Helsinki Declaration.

\section{Measures}

Parental socioeconomic status was assessed at the baseline (referred to as Year 0, the subjects being 3-18 years of age). Following a method used by Pulkki et al. (2003) in an earlier CRYF study, SES was measured by two indices: (a) the mother's and father's years of education and (b) the annual income of the household (measured on an eightpoint scale). In the CRYF sample the correlation between the mother's and the father's years of education was $r=.66$, and the correlation between these two measures and household income was $r=.45$ and $r=.50$, respectively (all $P$ values $<.001$ ). The SES indicator was constructed by calculating first the mean of the years of education of the mother and the father and then standard- 
Table 1 Descriptive statistics $(n=1246)$

\begin{tabular}{|c|c|c|c|}
\hline & & $n(\%)$ & Mean (SD) \\
\hline Gende & & & \\
\hline Men & & 559 (45.9) & \\
\hline Wor & & $687(55.1)$ & \\
\hline HTR2 & lotype & & \\
\hline $\mathrm{T} / \mathrm{T}$ & & 129 (10.4) & \\
\hline $\mathrm{T} / \mathrm{C}$ & & $548(44.0)$ & \\
\hline $\mathrm{C} / \mathrm{C}$ & & 569 (45.6) & \\
\hline Age a & & & $10.9(5.0)$ \\
\hline Year & dance & & $91.2(18.0)$ \\
\hline Year & dance & & $90.0(18.5)$ \\
\hline Subje & (years) & & $14.6(3.0)$ \\
\hline Mothe & (years) & & $10.0(3.2)$ \\
\hline Father & (years) & & $9.7(3.7)$ \\
\hline House & & & $4.8(1.9)$ \\
\hline & & & $0.0(1.7)$ \\
\hline $\begin{array}{l}\text { Note: } \\
\text { indica } \\
\text { housel }\end{array}$ & $\begin{array}{l}\text { ncome } \\
\text { ted from } \\
\text { cores (see }\end{array}$ & $\begin{array}{l}\text { ured on a } \\
\text { rdized par }\end{array}$ & $\begin{array}{l}\text { scale. SES } \\
\text { ucation and }\end{array}$ \\
\hline Table & $r$ of sub & gender and & ear 21 \\
\hline Age & Gender & & \\
\hline & Women & Men & Total \\
\hline 24 & 90 & 91 & 181 \\
\hline 27 & 137 & 72 & 209 \\
\hline 30 & 107 & 97 & 204 \\
\hline 33 & 122 & 85 & 207 \\
\hline 36 & 118 & 116 & 234 \\
\hline 39 & 113 & 98 & 211 \\
\hline Total & 687 & 559 & 1246 \\
\hline
\end{tabular}

izing the mean into a $\mathrm{Z}$ score. Twelve percent of the subjects were living in single-parent households, for whom parental education was determined by the years of education of the single parent. Next, the annual income of the household was standardized into a $\mathrm{Z}$ score, and then the $\mathrm{Z}$ scores of education and income were summed, resulting in an index of parental socioeconomic status.

In order to evaluate the stability of parental SES, it was also assessed in the first follow-up of the CRYF, three years after the baseline. The correlation between baseline and Year-3 parental SES was $r=.94(P<.001)$ in the total CRYF sample $(n=2174)$. Given the very high stability, statistical analyses were carried out with the baseline assessment only, for which we had complete data on all the participants.

Assessments of temperament were made 17 and 21 years after the baseline (Years 17 and 21, subjects being
20-35, and 24-39 years of age, respectively). Harm avoidance was measured with the Temperament and Character Inventory (TCI) developed by Cloninger et al. (1993). The HA scale consists of 35 items which were selfrated by the subjects on a five-point scale ranging from totally disagree (1) to totally agree (5). The Cronbach's alpha reliability was $\alpha=.92$ for both Year-17 and Year-21 HA. The correlation between Year-17 and Year-21 HA was $r=.78(P<.001)$.

The subject's own adulthood socioeconomic status was measured by years of education of the subject. Data on the subject's adulthood income was not available.

\section{HTR2A 102 T>C (34 S/S) genotyping}

Genomic DNA was extracted from peripheral blood using a commercially available kit (Qiagen Inc., Hilden, Germany). DNA samples were genotyped by employing the 5 , nuclease assay and fluorogenic TaqMan MGB probe (Livak 1999) using the ABI Prism 7900HT Sequence Detection System (Applied Biosystems, Foster City, CA, USA). The nucleotide sequences of primers and allelespecific probes, labeled with the reporter dyes FAM or VIC, were deduced from sequences deposited in the GenBank database and synthesized in conjugation with Applied Biosystems using the TaqMan ${ }^{\circledR}$ Validated SNP Genotyping Assay (SNP rs6313, assay ID: C-3042197-1). PCR reaction containing genomic DNA, $1 \times$ Universal PCR Master Mix, $900 \mathrm{nM}$ of each primer and $200 \mathrm{nM}$ of each probe was performed in 96-well plates using the standard protocol in a total volume of $25 \mu \mathrm{l}$. After PCR amplification, the endpoint reading of the fluorescence signal generated from each probe was measured by the allelic discrimination analysis module, resulting in clear identification of three genotypes.

\section{Statistical analysis}

The main effects of the HTR2A gene were assessed with univariate analysis of covariance (controlling for age and gender) and the main effects of SES with linear regression analysis (controlling for age, gender and adulthood years of education). Multiple regression analysis was used to assess the association of the HTR2A gene (coded as a continuous variable representing the number of $\mathrm{C}$-alleles: $\mathrm{T} / \mathrm{T}=0$, $\mathrm{T} / \mathrm{C}=1, \mathrm{C} / \mathrm{C}=2$ ), parental SES and their interaction on harm avoidance, with gender, age and adulthood years of education as covariates. Three separate regression models were tested, with the dependent variables being (1) Year-17 HA, (2) Year-21 HA, and (3) the mean of those two measurements, which was calculated for subjects who had data on both assessment times. 


\section{Results}

The descriptive statistics of the sample and study variables are shown in Tables 1 and 2 .

Table 3 shows harm avoidance scores by genotype groups. There was a linear association between T102C polymorphism and Year-21 HA, such that the $\mathrm{C} / \mathrm{C}$ genotype group had the highest and the T/T genotype group the lowest HA $(P=.019$, linear contrast $P=.027)$. The other findings were in line with this. Even though there were no significant differences in Year-17 HA between genotype groups, the $\mathrm{C} / \mathrm{C}$ genotype group tended to score slightly higher on HA than the others. The association between the T102C polymorphism and mean HA was significant $(P=.038)$. This association was not linear (linear contrast $P=.28$ ) but the $\mathrm{C} / \mathrm{C}$ genotype group had significantly higher mean HA than the others $(P=.047$; Table 3$)$. The T102C was not associated with parental SES $(P=.88)$ or with the subject's own education $(P=.99)$, indicating that there was no gene-environment correlation between the $\mathrm{T} 102 \mathrm{C}$ and indicators of socioeconomic status.

High parental SES predicted low adulthood HA (Year17 HA: $\mathrm{b}=-.96, \mathrm{SE}=.33, \beta=-.09, P=.004$; Year-21 HA: $\mathrm{b}=-1.21, \mathrm{SE}=.32, \beta=-.11, P<.001$; Mean HA: $\mathrm{b}=-1.10, \mathrm{SE}=.33, \beta=-.11, P<.001)$. The adulthood education level of the subject was also associated with lower Year-21 HA $(\mathrm{b}=-.51, \mathrm{SE}=.17, \quad \beta=-.08$, $P=.003)$ and Mean HA $(\mathrm{b}=-.43, \mathrm{SE}=.18, \beta=-.08$,
$P=.017)$, and there was a tendency in the same direction for Year-17 HA $(\mathrm{b}=-.29, \mathrm{SE}=.18, \beta=-.05, P=.106)$. The correlation between parental SES and subject's adulthood education was $r=.35(P<.001)$. Controlling for subject's adulthood education did not alter the association between parental SES and HA (data not shown).

Next we examined whether the T102C polymorphism moderated the association between parental SES and adulthood HA. The interaction effect between the T102C polymorphism and parental SES on HA was statistically or marginally significant in each of the three models (Table 4), and showed that high SES predicted low HA in individuals carrying the T/T or T/C genotype (Year-17 HA: $\mathrm{b}=-1.36, \mathrm{SE}=.50, \beta=-.12, P=.006$; Year-21 HA: $\mathrm{b}=-1.52, \mathrm{SE}=.46, \beta=-.14, P<.001 ;$ Mean HA: $\mathrm{b}=-$ $1.40, \mathrm{SE}=.49, \beta=-.14, P<.004)$, but not in those carrying the $\mathrm{C} / \mathrm{C}$ genotype (Year-17 $\mathrm{HA}: \mathrm{b}=-.44, \mathrm{SE}=.51$, $\beta=-.04, P=.386 ;$ Year-21 HA: $\mathrm{b}=-.42, \mathrm{SE}=.50$, $\beta=-.04, P=.403$; Mean HA: $\mathrm{b}=-.39, \mathrm{SE}=.52, \beta=-$ $.04, P=.453)$.

The interaction effect between the T102C polymorphism and parental SES was further illustrated by categorizing the subjects according to level of childhood SES (low group $=$ lowest $25 \%$, high group $=$ highest $25 \%$ of subjects), and examining the levels of HA as a function of the T102C within these two groups with analysis of covariance (Fig. 1). Among subjects with high parental SES, the level of HA was linearly dependent on the T102C

Table 3 Harm avoidance (Mean \pm SD) by HTR2A T102C genotype groups

\begin{tabular}{|c|c|c|c|c|c|}
\hline & $\mathrm{T} / \mathrm{T}(n=129)$ & $\mathrm{T} / \mathrm{C}(n=548)$ & $\mathrm{C} / \mathrm{C}(n=569)$ & ANOVA & $\eta^{2}$ \\
\hline Year-17 HA $(n=1107)$ & $90.96(18.11)$ & $90.02(18.54)$ & $91.71(17.82)$ & $P=.405$ & - \\
\hline Year-21 HA $(n=1246)$ & $87.32(18.90)$ & $89.02(18.29)$ & $91.47(18.42)$ & $P=.019^{\mathrm{a}}$ & .01 \\
\hline Mean HA $(n=966)$ & $89.71(17.14)$ & $89.11(17.24)$ & $92.06(16.70)$ & $P=.038^{\mathrm{b}}$ & .01 \\
\hline
\end{tabular}

a Linear contrast $P=.027$;

b $\mathrm{C} / \mathrm{C}>\mathrm{T} / \mathrm{T} \& \mathrm{~T} / \mathrm{C} P=.047$

Table 4 Three separate linear regression models predicting Year-17, Year-21 and mean harm avoidance

\begin{tabular}{|c|c|c|c|c|c|c|}
\hline \multirow[t]{3}{*}{ Variable } & \multicolumn{6}{|c|}{ Harm avoidance } \\
\hline & \multicolumn{2}{|c|}{ Model 1: Year 17} & \multicolumn{2}{|c|}{ Model 2: Year 21} & \multicolumn{2}{|c|}{ Model 3: Mean } \\
\hline & $\mathrm{B}(\mathrm{SE})$ & $P$ & B (SE) & $P$ & $\mathrm{~B}(\mathrm{SE})$ & $P$ \\
\hline Gender & $-5.31(1.11)$ & 0.000 & $-7.56(1.05)$ & 0.000 & $-5.54(1.12)$ & 0.000 \\
\hline Age & $-0.01(0.11)$ & 0.897 & $0.04(0.10)$ & 0.677 & $0.07(0.11)$ & 0.549 \\
\hline Subject's education & $-0.08(0.20)$ & 0.676 & $-0.34(.018)$ & 0.068 & $-0.28(0.20)$ & 0.165 \\
\hline HTR2A & $0.75(0.84)$ & 0.375 & $2.15(0.78)$ & 0.006 & $1.73(0.83)$ & 0.036 \\
\hline Parental SES & $-3.15(1.22)$ & 0.010 & $-3.32(1.15)$ & 0.004 & $-3.05(1.20)$ & 0.011 \\
\hline HTR2A $\times$ parental SES & $0.94(0.50)$ & 0.058 & $0.99(0.47)$ & 0.035 & $0.90(0.49)$ & 0.065 \\
\hline Constant & $99.18(5.13)$ & 0.000 & $101.58(4.78)$ & 0.000 & $98.09(5.09)$ & 0.000 \\
\hline
\end{tabular}

Note: $n($ model 1$)=1107, n($ model 2$)=1246, n($ model 3$)=966$ 
Fig. 1 Harm avoidance (Mean \pm SE) by T102C genotype and childhood SES group
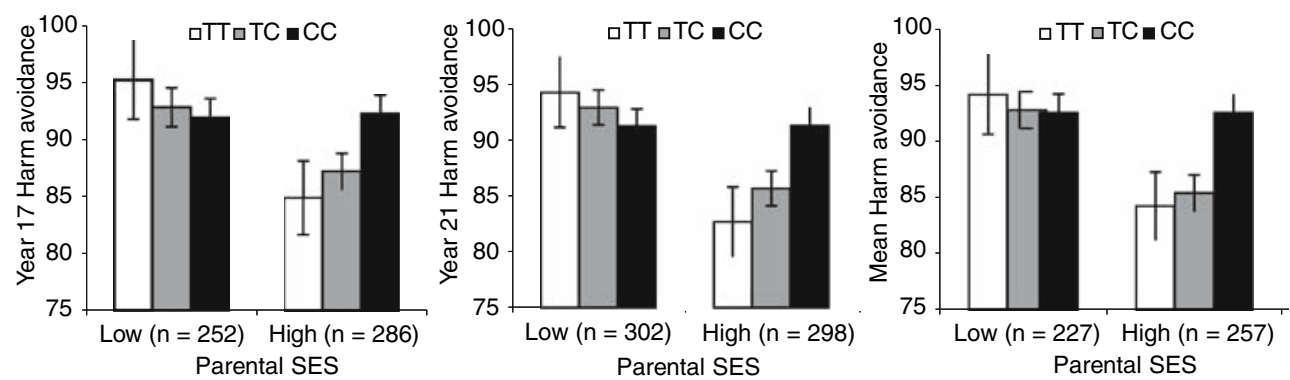

polymorphism, so that the number of $\mathrm{C}$ alleles was related to higher HA (Year-17 HA: $P=.029$, linear contrast $P=.044, \eta^{2}=.03$; Year-21 HA: $P=.012$, linear contrast $P=.017, \eta^{2}=.03$; Mean HA: $P=.003$, linear contrast $\left.P=.017, \eta^{2}=.05\right)$. Among subjects with low SES there was some evidence for an association in the opposite direction (i.e. higher HA for T-allele carriers; Fig. 1) but this effect was not statistically significant (all $P$ values $>.62)$.

\section{Discussion}

The present findings suggest a role of parental socioeconomic status (SES), the T102C polymorphism of the serotonin receptor $2 \mathrm{~A}$ gene (HTR2A), and their interaction in the development of harm avoidance (HA). First, we found that high parental SES in childhood and adolescence predicted low HA in adulthood independently of subjects' own adulthood educational level. Second, the $\mathrm{C}$ allele of the HTR2A T102C polymorphism was associated with high HA in one of the two test settings taken four years apart, and with the mean of those two measurements. The main finding was, however, an interaction between parental SES and T102C polymorphism, indicating that parental SES in childhood predicted HA in adulthood in the T/T or $\mathrm{T} / \mathrm{C}$ genotype carriers, but not in carriers of the $\mathrm{C} / \mathrm{C}$ genotype.

The main effect of the T102C polymorphism on HA was inconsistent (i.e., observed only in one of the two test settings), which has been the case across many molecular genetic studies examining only main effects (e.g., Munafò et al. 2005; see Ebstein 2006). In contrast, the T allele was consistently associated with low HA among those with high parental SES, while no statistically significant association was observed among those with low parental SES. The environmentally contingent association was more robust (i.e. observed in both of the two test settings) and greater in terms of magnitude than the main effect observed in the total sample (i.e. the T102C polymorphism accounted for $3-5 \%$ of the HA variance among individuals with high parental SES and only $1 \%$ in the total sample).
This finding lends support for the argument that the association between a genotype and a phenotype of interest should become more robust when individuals are stratified by relevant environmental exposure (Ebstein 2006).

Harm Avoidance has been suggested to reflect individual differences in serotonergic functioning and reactivity to aversive stimuli (Cloninger et al. 1987), and high HA has been shown to correlate with high stress vulnerability. In a study by Puttonen et al. (2005) individuals with high HA showed a high level of emotional distress and high physiological reactivity in terms of autonomous nervous system activation during a task-induced stress.

Early life experiences have been shown to induce longterm alterations in serotonergic functioning which, in turn, may be associated with individual stress vulnerability (Sánchez et al. 2001) Rhesus macaques raised in adverse rearing conditions exhibit serotonergic dysfunctions and heightened behavioral and neuroendocrinological reactions to stress (Bennett et al. 2002; Barr et al. 2004). With specific regard to serotonin receptors, Pine et al. (1996) found that exposure to harsh parenting was inversely related to the density of $5-\mathrm{HT}_{2 \mathrm{~A}}$ platelet receptors in a sample of adolescent boys. Thus, our finding of an association between high parental SES and low adulthood HA is in line with studies demonstrating an association between early life experiences, serotonin functioning, and stress vulnerability. The influence of parental SES on adulthood HA in carriers of the $\mathrm{T}$ allele was relatively small, the standardized regression coefficient being approximately $\beta=-.14$.

Studies on rhesus macaques have shown that an adverse impact of early rearing conditions on serotonergic functioning and stress vulnerability may be moderated by the serotonin transporter polymorphism rh5-HTTLPR (Bennett et al. 2002; Barr et al. 2004), suggesting that some genotypes may be more susceptible to environmental influences than others. The present gene-environment interaction involving the T102C polymorphism of the HTR2A gene indicates that the development of temperament in the T-allele carriers is influenced by parental SES, while the $\mathrm{C} /$ $\mathrm{C}$-genotype carriers may be insensitive to this aspect of the environment. This suggests that the $\mathrm{C} / \mathrm{C}$ genotype might render the $5-\mathrm{HT}_{2 \mathrm{~A}}$ receptors, and thereby temperament 
development, less susceptible to external influences. It would be of interest to examine this hypothesis in neurobiological studies measuring the function of $5-\mathrm{HT}_{2 \mathrm{~A}}$ receptors.

The $\mathrm{C}$ allele of the T102C polymorphism of the HTR2A gene has been associated with lower binding potential of the $5-\mathrm{HT}_{2 \mathrm{~A}}$ receptors (Turecki et al. 1999), and with lower $5-\mathrm{HT}_{2 \mathrm{~A}}$ receptor mRNA levels in postmortem brain (Polesskaya and Sokolov 2002), suggesting that the T102C polymorphism may have functional relevance, although this was not supported by a study by Bray et al. (2004). Furthermore, the T102C has been found to be in complete linkage disequilibrium with the $-1438 \mathrm{~A} / \mathrm{G}$ polymorphism of the HTR2A gene (e.g., Bray et al. 2004, Spurlock et al. 1998). In a recent study, Myers et al. (2007) reported that variation in gene expression was associated with the 1438A/G polymorphism of the HTR2A, and that this association was further moderated by the $-783 \mathrm{~A} / \mathrm{G}$ polymorphism. The interaction effect between the $-1438 \mathrm{~A} / \mathrm{G}$ and $-783 \mathrm{~A} / \mathrm{G}$ polymorphisms suggests that future behavior genetic studies of the HTR2A should consider the interactions between different polymorphisms of the HTR2A gene.

Children with high parental SES usually have better access to financial and social resources and are less likely to be exposed to stressful environmental influences than children with low parental SES (see Bradley and Corwyn 2002; Repetti et al. 2002). Here the association between the $\mathrm{T}$ allele of the T102C polymorphism and low HA was observed most clearly among individuals with high parental SES (see Fig. 1). We therefore suggest that a benevolent developmental environment may bring out the T102C allelic variance associated with HA. Conversely, the association between the $\mathrm{T}$ allele and low HA may be masked among individuals with low parental SES, where the environmental conditions necessary for this genetic association to manifest may not be available, and where all individuals tend to have high HA irrespective of their T102C genotype.

Findings of a single association study need to be interpreted with caution before they are replicated in other studies and samples. In another study with the same sample as here, we (Jokela et al. 2007) found that the T102C polymorphism moderated the association between exposure to maternal nurturance in childhood or adolescence and depressive symptoms in adulthood. High maternal nurturance predicted low depressive symptoms in individuals carrying the $\mathrm{T} / \mathrm{T}$ or $\mathrm{T} / \mathrm{C}$ genotype but not in those carrying the $\mathrm{C} / \mathrm{C}$ genotype. In the $\mathrm{CRYF}$ sample the correlation between the maternal nurturance scale and parental socioeconomic status is nonsignificant (Year 0: $r=-.03$, $P=.13$ ) or low (Year 3: $r=.09, P<.001$; unpublished data), so our two studies provide evidence for the moder- ating role of the HTR2A gene with two largely independent measures of the environment. The correlation between HA and depressive symptoms is $r=.45-.63$ ( $P<.001$; unpublished data, see Elovainio et al. 2004).

A recent meta-analysis (Abdolmaleky et al. 2004) concluded that there is an association between the $\mathrm{C}$ allele of the T102C polymorphism of the HTR2A gene and increased risk of schizophrenia. The T102C polymorphism has also been associated with suicidal behavior (Du et al. 2000) and depression, although inconsistently since different studies (Du et al. 2000; Eley et al. 2004) have associated both the $\mathrm{T}$ and the $\mathrm{C}$ alleles with increased risk of depression. Furthermore, the majority of studies of the T102C polymorphism have found no evidence for an association with depression at all (Anguelova et al. 2003). Our present finding may be relevant in the context of psychiatric disorders, since high HA is related to schizophrenia (Szöke et al. 2002) and depression (Farmer et al. 2003), among other outcomes. The association between the $\mathrm{C}$ allele and the development of psychiatric disorders found in previous studies might be due to limited responsivity of the $\mathrm{C}$ allele to the protective aspects of the environment. Moreover, the genetic risk may be highest among individuals with benevolent developmental environments, where the individual differences in T102C polymorphism of the HTR2A gene appear to be most pronouncedly expressed.

Acknowledgements We wish to thank Riikka Rontu for the genotyping. This study was financially supported by the Academy of Finland (grants no. 209514, 209518 and 1111056), Tampere University Hospital Medical Fund, Emil Aaltonen Foundation (TL), Yrjö Jahnsson's Foundation, Signe and Ane Gyllenberg's Foundation (LK$\mathrm{J})$, and the Finnish Cultural Foundation (MJ).

\section{References}

Åkerblom HK, Uhari M, Personen E, Dahl M, Kaprio EA, Nuutinen EM, Pietikäinen M, Salo MK, Aromaa A, Kannas L, Keltikangas-Järvinen L, Kuusela V, Räsänen L, Rönnemaa T, Knip M, Telama R, Välimäki I, Pyörälä K, Viikari J (1991) Cardiovascular risk in young Finns. Ann Med 23:35-40

Abdolmaleky HA, Faraone SV, Glatt SJ, Tsuang MT (2004) Metaanalysis of association between the T102C polymorphism of the 5HT2a receptor gene and schizophrenia. Schizophr Res 67:5362

Anguelova M, Benkelfat C, Turecki G (2003) A systematic review of association studies investigating genes coding for serotonin receptors and the serotonin transporter: I. Affective disorders. Mol Psychiatry 8:574-591

Barr CS, Newman TK, Shannon C, Parker C, Dvoskin RL, Becker ML, Schwandt M, Champoux M, Lesch KP, Goldman D, Suomi SJ, Higley JD (2004) Rearing condition and rh5-HTTLPR interact to influence limbic-hypothalamic-pituitary-adrenal axis response to stress in infant macaques. Biol Psychiatry 55:733-738

Bennett AJ, Lesch KP, Heils A, Long JC, Lorenz JG, Shoaf SE, Champoux M, Suomi SJ, Linnoila MV, Higley JD (2002) Early 
experience and serotonin transporter gene variation interact to influence primate CNS function. Mol Psychiatry 7:118-122

Berman SM, Noble EP (1997) The D2 dopamine receptor (DRD2) gene and family stress: interactive effects on cognitive functions in children. Behav Genet 27:33-44

Bolger N, Schilling EA (1991). Personality and the problems of everyday life: the role of neuroticism in exposure and reactivity to daily stressors. J Personality 59:355-386

Bradley RH, Corwyn RF (2002). Socioeconomic status and child development. Annu Rev Psychol 53:371-399

Bray NJ, Buckland PR, Hall H, Owen MJ, O’Donovan MC (2004) The serotonin-2A receptor gene locus does not contain common polymorphism affecting mRNA levels in adult brain. Mol Psychiatry 9:109-114

Caspi A, Sugden K, Moffitt TE, Taylor A, Craig IW, Harrington HL, McClay J, Mill J, Martin J, Braithwaite A, Poulton R (2003) Influence of life stress on depression: moderation by a polymorphism in the 5-HTT gene. Science 301:386-389

Cloninger CR (1987) A systematic method for clinical description and classification of personality variants: a proposal. Arch Gen Psychiatry 44:573-588

Cloninger CR, Svrakic DM, Przybeck TR (1993) A psychobiological model of temperament and character. Arch Gen Psychiatry 50:975-990

Du L, Bakish D, Lapierre YD, Ravindran AV, Hrdina PD (2000) Association of polymorphism of serotonin $2 \mathrm{~A}$ receptor gene with suicidal ideation in major depressive disorder. Am J Med Gen 96:56-60

Ebstein RP (2006) The molecular genetic architecture of human personality: beyond self-report questionnaires. Mol Psychiatry 11:427-445

Eley TC, Sugden K, Corsico A, Gregory AM, Sham P, McGuffin P, Plomin R, Craig IW (2004). Gene-environment interaction analysis of serotonin system markers with adolescent depression. Mol Psychiatry 9:908-916

Elovainio M, Kivimaki M, Puttonen S, Heponiemi T, Pulkki L, Keltikangas-Jarvinen L (2004). Temperament and depressive symptoms: a population-based longitudinal study on Cloninger's psychobiological temperament model. J Affect Disord 83: 227232

Fanous A, Gardner CO, Prescott CA, Cancro R, Kendler KS (2002) Neuroticism, major depression and gender: a population-based twin study. Psychol Med 32:719-728

Farmer A, Mahmood A, Redman K, Harris T, Sadler S, McGuffin P (2003) A sib-pair study of the temperament and character inventory scales in major depression. Arch Gen Psychiatry 60:490-496

Fox NA, Nichols KE, Henderson HA, Rubin K, Schmidt L, Hamer D, Ernst M, Pine DS (2005) Evidence for a gene-environment interaction in predicting behavioral inhibition in middle childhood. Psychol Sci 16:921-926

Grabe HJ, Lange M, Wolff B, Völzke H, Lucht M, Freyberger HJ, John U, Cascorbi I (2005). Mental and physical distress is modulated by a polymorphism in the 5-HT transporter gene interacting with social stressors and chronic disease burden. Mol Psychiatry 10:220-224

Hansenne M, Ansseu M (1999). Harm avoidance and serotonin. Biol Psychol 51:77-81

Jokela M, Keltikangas-Järvinen L, Kivimäki M, Puttonen S, Elovainio M, Rontu R, Lehtimäki T (2007) Serotonin receptor 2A gene and the influence of childhood maternal nurturance on adulthood depressive symptoms. Arch Gen Psychiatry 64:356-360

Keltikangas-Järvinen L, Räikkönen K, Ekelund J, Peltonen L (2004) Nature and nurture in novelty seeking. Mol Psychiatry 9:308311
Keltikangas-Järvinen L, Ravaja N, Viikari J (1999) Identifying Cloninger's temperament profiles as related to the early development of the metabolic cardiovascular syndrome in young men. Arterioscler Thromb Vasc Biol 19:1998-2006

Kochanska G (1991) Socialization and temperament in the development of guilt and conscience. Child Dev 62:1379-1392

Kusumi I, Suzuki K, Sasaki Y, Kameda K, Sasaki T, Koyama T (2002) Serotonin 5- $\mathrm{HT}_{2 \mathrm{~A}}$ receptor gene polymorphism, 5- $\mathrm{HT}_{2 \mathrm{~A}}$ receptor function and personality traits in healthy subjects: a negative study. J Affect Disord 68:235-241

Livak KJ (1999) Allelic discrimination using fluorogenic probes and the 5' nuclease assay. Genet Anal 14:143-149

Manuck SB, Flory JD, Ferrell RE, Muldoon MF (2004) Socioeconomic status covaries with central nervous system serotonergic responsivity as a function of allelic variation in the serotonin transporter gene-linked polymorphic region. Psychoneuroendocrinology 29:651-668

McCrae RR, Costa PT Jr, Hrebícková M, Ostendorf F, Angleitner A, Avia MD, Sanz J, Sánchez-Bernardos ML, Kusdil ME, Woodfield R, Saunders PR, Smith PB (2000) Nature over nurture: temperament, personality, and life span development. J Pers Soc Psychol 78:173-186

Moresco FM, Dieci M, Vita A, Messa C, Gobbo C, Galli L, Rizzo G, Panzacchi A, de Peri L, Invernizzi G, Fazio F (2002) In vivo serotonin $5 \mathrm{HT}_{2 \mathrm{~A}}$ receptor binding and personality traits in healthy subjects: a positron emission tomography study. NeuroImage 17:1470-1478

Munafò MR., Clark T, Flint J (2005) Does measurement instrument moderate the association between the serotonin transporter gene and anxiety-related personality traits?. A meta-analysis Mol Psychiatry 10:415-419

Myers RL, Airey DC, Manier DH, Shelton RC, Sanders-Bush E (2007). Polymorphisms in the regulatory region of the human serotonin $5-\mathrm{HT}_{2 \mathrm{~A}}$ receptor gene (HTR2A) influence gene expression. Biol Psychiatry 61:167-173

Ozkaragoz T, Noble EP (2000) Extraversion: interaction between D2 dopamine receptor polymorphisms and parental alcoholism. Alcohol 22:139-146

Peirson AR, Heuchert JW, Thomala L, Berk M, Plein H, Cloninger CR (1999) Relationship between serotonin and the temperament and character inventory. Psych Res 89:29-37

Pine DS, Wasserman GA, Coplan J, Fried JA, Huang YY, Kassir S, Greenhill L, Shaffer D, Parsons B (1996) Platelet serotonin 2A $\left(5-\mathrm{HT}_{2 \mathrm{~A}}\right)$ receptor characteristics and parenting factors for boys at risk for delinquency: a preliminary report. Am J Psychiatry 153:538-544

Polesskaya OO, Sokolov BP (2002) Differential expression of the ' $\mathrm{C}$ ' and ' $\mathrm{T}$ ' alleles of the 5-HT2A receptor gene in the temporal cortex of normal individuals and schizophrenics. J Neurosci Res 67:812-822

Pulkki L, Keltikangas-Järvinen L, Ravaja N, Viikari J (2003) Childrearing attitudes and cardiovascular risk among children: moderating influence of parental socioeconomic status. Prev Med 36:55-63

Puttonen S, Ravaja N, Keltikangas-Järvinen L (2005) Cloninger's temperament dimensions and affective responses to different challenges. Compr Psychiatry 46:128-134

Raine A, Reynolds C, Venables P, Mednick S (2002). Stimulation seeking and intelligence: a prospective longitudinal study. J Pers Soc Psychol 82:663-674

Repetti RL, Taylor SE, Seeman TE (2002) Risky families: family social environments and the mental and physical health of offspring. Psychol Bull 128:330-366

Sánchez MM, Ladd OD, Plotsky PM (2001) Early adverse experience as a developmental risk factor for later psychopathology: 
evidence from rodent and primate models. Dev Psychopathol 13:419-449

Schüssler P, Gebhardt C, Leisch F, Fuchs K, Stompe T, Sieghart W, Kasper S, Hornik K, Aschauer HN (2000) Novelty seeking and harm avoidance and dopamine 4 and serotonin $2 \mathrm{~A}$ receptor gene polymorphisms. Eur Neuropsychopharmacol 10:398 (abstract)

Spurlock G, Heils A, Holmans P, Williams J, D'Souza UM, Cardno A, Murphy KC, Jones L, Buckland PR, McGuffin P, Lesch KP, Owen MJ (1998) A family based association study of T102C polymorphism in 5HT2A and schizophrenia plus identification of new polymorphisms in the promoter. Mol Psychiatry 3:42-49

Szöke A, Schürhoff F, Ferhadian N, Bellivier F, Rouillon F, Leboyer M (2002) Temperament in schizophrenia: a study of the tridimensional personality questionnaire (TPQ). Eur Psychiatry 17:379-383

Turecki G, Brière R, Dewar K, Antonetti T, Lesage AD, Séguin M, Chawky N, Vanier C, Alda M, Joober R, Benkelfat C, Rouleau GA (1999) Prediction of level of serotonin 2A receptor binding by serotonin receptor $2 \mathrm{~A}$ genetic variation in postmortem brain samples from subjects who did or did not commit suicide. Am J Psychiatry 156:1456-1458

van Heeringen C, Audenaert K, Van Laere K, Dumont F, Slegers G, Mertens J, Dierckx RA (2003) Prefrontal 5-HT2a receptor binding index, hopelessness and personality characteristics in attempted suicide. J Affect Disord 74:149-158 